\title{
Repression of the Alkaline Phosphatase of Vibrio cholerae
}

\author{
By NIRMAL K. ROY, RANAJIT K. GHOSH AND JYOTIRMOY DAS* \\ Department of Biophysics, Indian Institute of Experimental Medicine, Calcutta 700032 , \\ India
}

(Received 14 April 1981)

\begin{abstract}
The synthesis of alkaline phosphatase by two strains of Vibrio cholerae belonging to the Inaba and Ogawa serotypes has been examined in relation to the phosphate concentration of the culture medium. The synthesis of the enzyme in both strains was repressed in cells grown in the presence of a high concentration of inorganic phosphate. Lowering the phosphate content of the growth medium led to a derepression of enzyme activity. The presence of glucose in low phosphate medium stimulated the degree of derepression. The synthesis of the enzyme by strain Inaba 569B was more sensitive to inorganic phosphate than that of strain Ogawa 154. The enzyme was presumably located in the periplasmic space since it was released when the organisms were converted to spheroplasts.
\end{abstract}

\section{INTRODUCTION}

Vibrio cholerae, the causative agent of cholera, is composed of several different biotypes. The classical strains associated with epidemic cholera can ferment mannose and sucrose, but not arabinose (Mukherjee, 1978). The eltor biotype differs from the classical strains in phage susceptibility and some biochemical reactions (Mukherjee, 1978; Finkelstein, 1973). However, eltor strains react with anti- $V$. cholerae antisera and taxonomic studies have shown that these two biotypes are of the same species (Citerella \& Colwell, 1970; Colwell, 1970).

Interest in the study of $V$. cholerae has recently increased because of considerable progress in the understanding of the molecular mechanisms involved in the action of cholera toxin (Finkelstein et al., 1974; Mekalanos et al., 1978, 1979). Some important advances have been made in the study of the genetic regulation of toxin production (Baine et al., 1978; Gerdes \& Romig, 1975; Parker et al., 1979) and transfection has been demonstrated in this system (Balganesh \& Das, 1979).

A possible correlation between the amount of toxin produced and the physiology of classical vibrios has been predicted (Honda \& Finkelstein, 1979). While strain Ogawa 154 is a mild toxinogenic strain of $V$. cholerae, strain Inaba 569B is a hyper-toxin-producing strain (Mukherjee, 1978; Finkelstein, 1973). We have studied the alkaline phosphatase (APase) from these two strains of $V$. cholerae to examine whether this enzyme might be used as an indicator of serotype or as a marker of toxicity. Synthesis of APase in micro-organisms can be regulated by varying the concentration of $P_{i}$ in the growth medium: APase synthesis is repressed in medium in which the $P_{i}$ content is high (Willsky \& Malamy, 1976). It has recently been postulated that at least two regulatory genes might be controlling the structural gene for APase (Brickman \& Beckwith, 1975; Kreuzer et al., 1975). Several features of this enzyme and some unusual aspects concerning the regulation of its synthesis have made this protein intriguing for further study.

The results presented here show that the APases from $V$. cholerae strains 154 and 569B are periplasmic enzymes and are repressed when the organisms are grown in the presence of high concentrations of $\mathbf{P}_{\mathbf{i}}$. 


\section{METHODS}

Organisms and growth media. Vibrio cholerae Ogawa 154 and Inaba 569B strains were obtained from the Cholera Research Center, Calcutta, India. Cultures were stored in a lyophilized state or as frozen stocks at $-40^{\circ} \mathrm{C}$ in nutrient broth containing $15 \%(\mathrm{v} / \mathrm{v})$ glycerol. Every 2 months cultures were passaged through guinea-pigs and stock cultures were prepared from single colonies after proper identification of the strain (Mukherjee, 1978).

Cultures were grown at $37^{\circ} \mathrm{C}$ in nutrient broth containing $10 \mathrm{~g}$ bacteriological peptone (Oxoid), $10 \mathrm{~g}$ Lab-Lemco (meat extract) powder (Oxoid), and $5 \mathrm{~g} \mathrm{NaCl}$ per litre distilled water. The $\mathrm{pH}$ of the medium was adjusted to 7.4. Cell growth was assayed by measuring turbidity at $540 \mathrm{~nm}\left(A_{540}\right)$ using a Gilford model 250 spectrophotometer (an $A_{540}$ of 1.0 corresponded to $1.2 \times 10^{9}$ cells ml ${ }^{-1}$ ). The $\mathrm{P}_{\mathrm{i}}$ content of the nutrient broth was estimated by the method of Ernster et al. (1950) and was found to be $2.5 \mathrm{~mm}$. This medium is referred to as the high phosphate (HP) medium. The low phosphate (LP) medium was phosphate-depleted nutrient broth. To prepare this, magnesia mixture $(40 \mathrm{ml})$ was added to 1 litre nutrient broth (Ghosh et al., 1971) and kept at $4{ }^{\circ} \mathrm{C}$ overnight. The precipitate was removed by filtration and the $\mathrm{pH}$ was adjusted to $7 \cdot 4$. The $\mathrm{P}_{1}$ content of this medium was $25 \mu \mathrm{M}$. In some experiments, $0.1 \%(\mathrm{w} / \mathrm{v})$ glucose was added to the low phosphate medium; this medium is referred to as $L$ PG medium.

Growth conditions. Cells were grown in $40 \mathrm{ml} \mathrm{HP}$ medium for $18 \mathrm{~h}$ with shaking at $37^{\circ} \mathrm{C}$ and centrifuged at $5000 \mathrm{~g}$ for $10 \mathrm{~min}$. The cell pellet was washed once and resuspended in $2.5 \mathrm{ml} \mathrm{LP}$ medium. This suspension was used to inoculate $100 \mathrm{ml} \mathrm{LP}$ medium in a $500 \mathrm{ml}$ Erlenmeyer flask to give an initial $A_{540}$ of $0 \cdot 08$. The suspension was incubated at $37^{\circ} \mathrm{C}$ with shaking $\left(180 \mathrm{rev} . \mathrm{min}^{-1}\right)$ and samples were removed at appropriate intervals for assaying enzyme activity either in the whole culture or in the cell pellet.

Spheroplast formation. Cells grown to an $A_{540}$ of 1.2 were harvested by centrifugation $(9000 \mathrm{~g}, 5 \mathrm{~min})$ and resuspended in $0.033 \mathrm{M}$-Tris $/ \mathrm{HCl}$ buffer $(\mathrm{pH} 8.0)$ containing $20 \%(\mathrm{w} / \mathrm{v})$ sucrose. The cell suspension was chilled to $0^{\circ} \mathrm{C}$ and treated successively with 0.1 vol. $0.1 \mathrm{M}$-EDTA $\left(\mathrm{pH} 8.0\right.$ ) and $5 \mu \mathrm{g}$ lysozyme $\mathrm{ml}^{-1}$. Mixing was achieved by gently rolling the suspension at $0^{\circ} \mathrm{C}$. Spheroplast formation required about 8 to 10 min and was monitored by the method of Malamy and Horecker (1964).

Assay of alkaline phosphatase (APase). APase was assayed by monitoring the release of $p$-nitrophenol from $p$-nitrophenylphosphate (PNPP). One unit of the enzyme activity is defined as the amount of enzyme that liberates $1 \mathrm{nmol} p$-nitrophenol $\mathrm{min}^{-1}$ under the conditions of assay. The reaction mixture contained $2 \mathrm{~mm}-p$ nitrophenylphosphate, $1 \mathrm{mM}-\mathrm{MgCl}_{2}$ and the enzyme in a final volume of $2 \mathrm{ml} 1 \mathrm{M}$-Tris/ $\mathrm{HCl}$ buffer ( $\mathrm{pH} \mathrm{8.0).} \mathrm{The}$ reaction was carried out at $37^{\circ} \mathrm{C}$ for $15 \mathrm{~min}$, and then terminated by adding $0.2 \mathrm{ml} 26 \%\left(\mathrm{w} / \mathrm{v}\right.$ ) $\mathrm{K}_{2} \mathrm{HPO}_{4}$. Cell debris was removed by centrifugation at $9000 \mathrm{~g}$ for $5 \mathrm{~min}$. The absorbance of the supernatant was read at $410 \mathrm{~nm}$ $\left(A_{410}\right)$ on a Gilford model 250 spectrophotometer. The stability of the enzyme during assay was checked by the method of Selwyn (1965).

APase activity in the whole culture was assayed by adding $0.2 \mathrm{ml}$ culture to the reaction mixture. For assaying activity in the cell pellet, the whole culture was centrifuged at $9000 \mathrm{~g}$ for $5 \mathrm{~min}$ and the pellet was resuspended in same volume of $10 \mathrm{mM}$-Tris $/ \mathrm{HCl}$ buffer ( $\mathrm{pH} 8.0$ ) containing $1 \mathrm{mM}-\mathrm{MgCl}_{2}$ and $1 \mathrm{mM}-\mathrm{CoCl}_{2} ; 0.2 \mathrm{ml}$ of this suspension was added to the reaction mixture as the enzyme source. The activity released into the medium was measured by assaying $0.2 \mathrm{ml}$ of the $9000 \mathrm{~g}$ supernatant fraction.

\section{RES ULTS}

\section{Dependence of APase synthesis in $V$. cholerae on $P_{\mathrm{i}}$ content of growth medium}

Synthesis of APase by $V$. cholerae in media containing low (LP, $25 \mu \mathrm{M})$ or high (HP, 2.5 $\mathrm{mM}$ ) concentrations of $\mathrm{P}_{i}$ was examined. Growth of both strain Inaba 569B and strain Ogawa 154 was reduced by 30 to $40 \%$ in LP medium compared with growth in HP medium. The initial lag in growth in LP and LPG media relative to that in HP medium was longer for strain 154 than for strain 569B (data not shown). However, APase synthesis was totally repressed in both strains grown in HP medium. Derepression of APase activity was observed when cells were grown in LP medium, and this derepression was enhanced in LPG medium, i.e. LP medium containing $0.1 \%$ glucose (Fig. 1). Synthesis of the enzyme began after an initial lag of about $2 \mathrm{~h}$ in both LP and LPG media. While enzyme production increased linearly with growth in LP medium, in LPG medium the activity increased much more rapidly to a maximum in about $5 \mathrm{~h}$. The maximum enzyme activity was about twofold higher in LPG medium than in LP medium (Fig. 1).

To determine the minimum concentration of $P_{1}$ required to repress APase synthesis in $V$. cholerae, cells were grown in LP or LPG medium supplemented with various amounts of $\mathrm{P}_{1}$ 


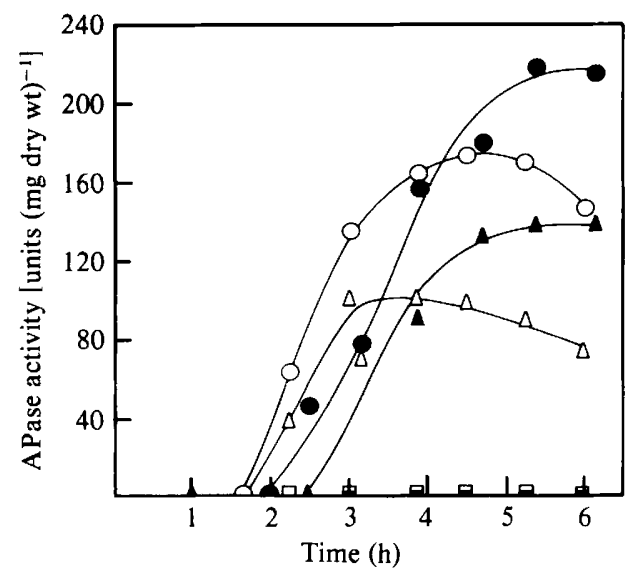

Fig. 1

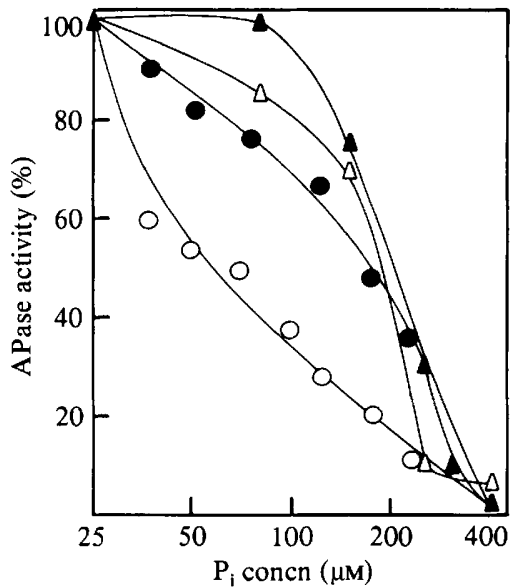

Fig. 2

Fig. 1. APase production by $V$. cholerae in high and low phosphate media. Samples $(5 \mathrm{ml})$ were removed at various times during growth and assayed for enzyme production as described in Methods. APase activity in strains 569B (open symbols) and 154 (closed symbols) grown in HP medium $(\square, \square$ ), in LP medium $(\triangle, \Delta)$ and in LPG medium $(O, O)$.

Fig. 2. Effect of $\mathrm{P}_{\mathrm{i}}$ concentration in the growth medium on APase synthesis by $V$. cholerae. Cells were grown to an $A_{540}$ of 1.2 in LP and LPG media supplemented with different amounts of $\mathrm{P}_{\mathrm{i}}$ and harvested by centrifugation $(9000 \mathrm{~g}, 5 \mathrm{~min})$. APase activity was assayed in the cell pellet. Activity in strain 154 grown in LP $(\triangle)$ and LPG $(\triangle)$ media and in strain 569B grown in LP $(O)$ and LPG $(O)$ media $[100 \%$ activity represents 80 and 120 units (mg dry wt) ${ }^{-1}$ for strain 154 grown in LP and LPG medium, respectively, and 100 and 150 units $(\mathrm{mg} \text { dry wt) })^{-1}$ for strain $569 \mathrm{~B}$ grown in LP and LPG medium, respectively].

and the enzyme activity was assayed in the cell pellet (Fig. 2). Synthesis of the enzyme was more sensitive to repression by $P_{i}$ in strain 569B than in strain 154 . The presence of up to 100 $\mu \mathrm{M}-\mathrm{P}_{1}$ had very little effect on APase synthesis in strain 154 grown in LPG medium and the activity was only $15 \%$ lower when grown in LP medium. In contrast, APase activity in strain 569B grown in LPG and LP media was decreased by more than $30 \%$ and $70 \%$, respectively, in the presence of $100 \mu \mathrm{M}-\mathrm{P}_{\mathrm{i}}$. At higher concentrations of $\mathrm{P}_{\mathrm{i}}$, a progressive repression of APase synthesis was observed in both strains and total repression occurred at $400 \mu \mathrm{M}$ (Fig. 2).

\section{Distribution of APase in different subcellular fractions}

To determine whether APase in $V$. cholerae cells was intracellular or was released into the medium, cells at different phases of growth in LP or LPG media were harvested and the enzyme activity was assayed in the cell pellet and in the culture supernatant. The total APase activity in the pellet and in the supernatant were compared with the activity in the same volume of the whole culture. About $90 \%$ of the whole culture APase activity was recovered in the pellet of strain 569B (Table 1). During the stationary phase of growth activity amounting to about $10 \%$ of the activity present in the cell pellet was released into the supernatant. Similar results were obtained for cells grown in LP or LPG medium. In contrast, with strain 154 , not more than $70 \%$ of the whole culture activity was recovered in the cell pellet (Table 1). No measurable APase activity was found in the culture supernatant. Recovery of activity in the cell pellet of strain 154 was dependent on the age of the culture: the recovered activity increased to a maximum during the late-exponential phase of growth and then decreased. To 


\section{Table 1. Distribution of APase activity in different subcellular fractions}

Cells were grown in LPG medium to an $A_{540}$ of 1.2 and harvested by centrifugation $(9000 \mathrm{~g}, 5 \mathrm{~min})$. Spheroplasts were formed as described in Methods. Enzyme activity is expressed relative to that in the whole culture [ 120 and 150 units (mg dry wt) $)^{-1}$ for strains 154 and $569 \mathrm{~B}$, respectivelyl.

\begin{tabular}{lcc}
$\quad$ Fraction & \multicolumn{2}{c}{ APase activity (\%) } \\
\cline { 2 - 3 } Whole culture & 67 & 100 \\
Strain 154 & strain 569B \\
Cell pellet & ND & 11 \\
Spheroplasts & 40 & 80 \\
Periplasmic supernatant* & & \\
$\quad$ ND, No detectable activity. & & \\
* Activity in the supernatant after spheroplast formation.
\end{tabular}

examine whether the incomplete recovery of activity in the cell pellet was due to some cofactor(s) released into the supernatant, in some experiments the supernatant was added to the reaction mixture. No increase in recovery was observed (data not shown). Toluene treatment or sonication of the cell suspension did not result in increased recovery of the activity from strain 154 .

More than $60 \%$ of the activity in the cell pellet was recovered in the supernatant after spheroplast formation from strain 154 (Table 1) and no enzyme activity was detected in the spheroplasts. With strain $569 \mathrm{~B}$, more than $85 \%$ of the activity in the cell pellet was released in the supernatant after spheroplast formation and about $10 \%$ was retained in the spheroplasts (Table 1). These results suggest that the enzymes of both strains are located in the periplasmic space. Incomplete recovery of APase activity in the cell pellet of strain 154 was not due to any protease degradation. However, the activity of the enzyme was stable under the assay condition used in this study as determined by the criterion described by Selwyn (1965) (data not shown).

When $V$. cholerae APase activity in culture grown in LPG medium was assayed in the standard reaction mixture supplemented with various concentrations of $\mathrm{NaCl}$ and $\mathrm{MgCl}_{2}, \mathrm{a}$ gradual decrease in the enzyme activity was observed with increasing concentration of these salts. About $80 \%$ inhibition of APase activity occurred in presence of $250 \mathrm{~mm}-\mathrm{NaCl}$ in both strains. Inhibition of enzyme activity was more pronounced in the presence of $\mathrm{Mg}^{2+}: 60-80 \%$ inhibition of activity was observed in presence of $20 \mathrm{mM}-\mathrm{MgCl}_{2}$. Biochemical studies on purified enzymes are in progress.

\section{DIS CUSSION}

The present study describes repression of APase activity in strains of classical vibrios belonging to the two serotypes Inaba and Ogawa (Mukherjee, 1978) which differ in their toxicity. The limiting concentration of $P_{i}$ resulting in the repression of APase synthesis varies for different organisms. Low concentrations $(10 \mu \mathrm{M})$ of $\mathrm{P}_{\mathrm{i}}$ repress the synthesis of this enzyme in E. coli (Torriani, 1960), yet up to about $500 \mu \mathrm{M}$ is required in some Bacillus species (Dobozy \& Hammer, 1969). While APase synthesis in strain 154 was minimally affected by the presence of up to $100 \mu \mathrm{M}-\mathrm{P}_{i}$, the expression of the enzyme of strain $569 \mathrm{~B}$ was reduced by more than $30 \%$ at this concentration.

The stimulation of APase derepression observed in the presence of glucose has not been demonstrated in any other Gram-negative organism. The mechanisms involved in APase repression or derepression by carbon sources have not been adequately explained. A possible role of gluconeogenic metabolism has been postulated from studies on APases of Gram-positive organisms (Hydrean et al., 1977).

The APase of $V$. cholerae can be released on spheroplast formation by lysozyme and EDTA. Although histochemical evidence is not available, it appears from the present study 
that the enzyme is presumably located in the periplasmic space. However, spheroplasts formed by treatment with penicillin did not release the enzyme in the spheroplast supernatant. A similar observation was reported from studies on E. coli APase (Malamy \& Horecker, 1964).

Subculture of strain 596B in the laboratory reduces its toxicity. It has been observed that in vivo stability of APase was reduced along with the toxicity of the strain. However, the stability of the enzyme from strain 154 was not affected by laboratory subculturing (unpublished observations). In addition, the capability of strain 569B to repair damage to DNA induced by ultraviolet light (Das et al., 1981) was also reduced with the reduction of toxicity. These functions can be restored by animal passage of these cells (Das et al., 1981; and unpublished observations). The APase thus might be useful as a marker of toxicity.

This investigation was supported by grants from the Council of Scientific and Industrial Research and the Indian Council of Medical Research, Government of India. We wish to thank members of the Biophysics Division for their help and encouragement and Mr S. N. Dey for excellent technical assistance.

\section{REFERENCES}

BaINE, W. M., VASIL, M. L. \& Holms, R. K. (1978). Genetic mapping of mutations in independently isolated nontoxinogenic mutants of Vibrio cholerae. Infection and Immunity 21, 194-200.

Balganesh, M. \& Das, J. (1979). Transfection of Vibrio cholerae by bacteriophage $\phi 149$ DNA. Biochemical and Biophysical Research Communications 90, 726-733.

Brickman, E. \& Beckwith, J. (1975). Analysis of the regulation of Escherichia coli alkaline phosphatase synthesis using deletions and $\phi 80$ transducing phages. Journal of Molecular Biology 96, 307-316.

Citerella, R. V. \& Colwell, R. R. (1970). Poly phasic taxonomy of genus Vibrio: polynucleotide sequence relationships among selected Vibrio species. Journal of Bacteriology 104, 434-442.

Colwell, R. R. (1970). Polyphasic taxonomy of genus Vibrio: numerical taxonomy of Vibrio cholerae, Vibrio parahemolyticus and related Vibrio species. Journal of Bacteriology 104, 410-433.

DAS, G., SIL. K. \& DAS, J. (1981). Repair of ultraviolet light induced DNA damage in Vibrio cholerae. Biochimica et biophysica acta 655, 413-420.

Dobozy, A. \& HAMmer, H. (1969). Some properties of alkaline phosphatase in Bacillus species. Acta microbiologica Academiae scientiarum hungaricae 16, $181-187$.

ERnSter, L., Zetterstrom, R. \& LindberG, O. (1950). A method for the determination of tracer phosphate in biological material. Acta chemica scandinavica 4, 942-947.

Finkelstein, R. A. (1973). Cholera. CRC Critical Reviews in Microbiology 2, 552-623.

Finkelstein, R. A., Vasil, M. L. \& Holms, R. K. (1974). Studies on toxinogenesis in Vibrio cholerae. I. Isolation of mutants with altered toxinogenicity. Journal of Infectious Diseases 129, 117-123.

Gerdes, J. C. \& Romig, W. R. (1975). Genetic basis of toxin production and pathogenesis in Vibrio cholerae: evidence against phage conversion. Infection and Immunity 11, 445-452.

Ghosh, B. K., Wouters, J. T. M. \& LAmpen, J. O. (1971). Distribution of the sites of alkaline phosphatase(s) activity in vegetative cells of Bacillus subtilis. Journal of Bacteriology 108, 928-937.
Honda, T. \& Finkelstein, R. A. (1979). Selection and characteristics of Vibrio cholerae mutant lacking the A (ADP-ribosylating) protein of the cholera enterotoxin. Proceedings of the National Academy of Sciences of the United States of America 76, 2052-2056.

Hydrean. C., Ghosh, A., Nallin, M. \& Ghosh, B. K. (1977). Interrelationship of carbohydrate metabolism and alkaline phosphatase synthesis in Bacillus licheniformis 749/C. Journal of Biological Chemistry 252, 6806-6812.

Kreuzer. K., Pratt, C. \& Torriani, A. (1975). Genetic analysis of regulatory mutants of alkaline phosphatase of E. coli. Genetics 81, 459-468.

Malamy, M. H. \& Horecker, B. L. (1964). Release of alkaline phosphatase from cells of Escherichia coli upon lysozyme spheroplast formation. Biochemistry 3, 1889-1893.

Mekalanos, J. J., Collier, R. J. \& Romig, W. R. (1978). Affinity filters, a new approach to the isolation of tox mutants of Vibrio cholerae. Proceedings of the National Academy of Sciences of the United States of America 75, 941-945.

Mekalanos, J. J., Collier, R. J. \& Romig, W. R. (1979). Enzymatic activity of cholera toxins. I. New method of assay and the mechanism of ADP ribosyl transfer. Journal of Biological Chemistry 254, 5849-5854.

MuknerJeE, S. (1978). Principles and practice of typing Vibrio cholerae. Methods in Microbiology 12, $74-115$.

Parker, C., Gauthier, D., TATe, A., Richardson, K. \& RomiG, W. R. (1979). Expanded linkage map of Vibrio cholerae. Genetics 91, 191-214.

SELWYN, M. J. (1965). A simple test for inactivation of an enzyme during assay. Biochimica et biophysica acta 105, 193-195.

TORRIANI, A. (1960). Influence of inorganic phosphate in the formation of phosphatases by Escherichia coli. Biochimica et biophysica acta 38, 460-469.

Willsky, C. R. \& MALAMY, M. H. (1976). Control of synthesis of alkaline phosphatase and the phosphate binding protein in Escherichia coli. Journal of Bacteriology 127, 595-609. 